\title{
Spawanie w przemyśle włókienniczym w trzeciej dekadzie XX wieku (z teki Jacka Lassocińskiego)
}

\section{Welding in the textile industry in third decade of twentieth century (from Jacek Lassociński's portfolio)}

\section{Streszczenie}

W artykule przedstawiono zastosowanie metod spawalniczych w przemyśle włókienniczym stosowanych w latach trzydziestych dwudziestego wieku. Przedstawiono również krótką charakterystykę maszyn stosowanych w tym okresie do przędzenia.

\section{Wstęp}

Spawanie części maszyn znalazło zastosowanie nie tylko w przemyśle metalowym, ale również w innych gałęziach przemysłu, w tym w przemyśle włókienniczym. We włókiennictwie wykorzystywano spawanie do wytwarzania elementów oraz naprawy zużytych części. Szczególnie szeroko stosowano spawanie w farbiarstwie.

Niszczące działanie środków barwiących, o właściwościach żrących, znacznie zmniejszało czas pracy urządzeń. Straty z powodu korozji metali wynosiły ok. pół miliarda złotych, a korozja niszczyła rocznie 1/5 całkowitej produkcji stali [1].

Początkowo, celem zapobieżenia stratom, szukano metali odpornych chemicznie. Zaczęto wytwarzać materiały o specjalnym składzie chemicznym: stal Armco, Apso, Monel, Staybut itp. Dodatkowo zaczęto stosować spawanie, dzięki czemu uniknięto połączeń nitowanych, w których płyny dostawały się między blachy, co przyspieszało niszczenie elementów.

\section{Spawanie w przemyśle}

Metodą spawania wytwarzano rury wodne i wentylacyjne, aparaty do mielenia i rozpuszczania chlorku

Dr inż. Anna Pocica - Politechnika Opolska. wapnia, osie, wrzeciona itp., aparaty do prania, kwaszenia, chlorowania, cylindry i walce kalandrów, maszyny do karbonizowania przędzy Inianej, suszarki bębnowe na gorące powietrze, maszyny do apretury itp. Głównie jednak spawanie stosowano do naprawy uszkodzonych części lub napawania części zużytych. Ponieważ w budowie maszyn przędzalniczych i tkackich głównym materiałem konstrukcyjnym było żeliwo, więc naprawy wykonywano przy użyciu spoiwa w postaci prętów żeliwnych, albo za pomocą lutospawania - przy użyciu spoiwa mosiężnego. Maszyny włókiennicze przeważnie składały się z wielu drobnych części, o niezbyt skomplikowanych kształtach, w związku z czym ich naprawa nie przedstawiała większych trudności [1, 2]. Uszkodzone elementy naprawiono szybko. Jako zjawisko charakterystyczne można przytoczyć fakt, że w pewnych wielkich zakładach przędzalniczych, gdzie trzech spawaczy pracuje stale przy naprawach, w warsztacie naprawczym trudno zobaczyć jednocześnie kilka naprawianych części, ponieważ w bardzo krótkim czasie po wejściu do warsztatów idą one z powrotem do fabryki [2].

\section{Urządzenia do przędzenia}

Maszyny, stosowane w przemyśle włókienniczym, ze względu na ich przeznaczenie, można połączyć w kilka grup: trzeparki (rys. 1), które usuwały z włókien zanieczyszczenia, zgrzeblarki (rys. 2) 
do ostatecznego oczyszczania włókien i łączenia ich w zgrzebło taśmowe, wrzecioniarki (rys. 3), które zmniejszały grubość włókien, lekko je skręcając, i przędzarki (rys. 4): ciągłe, okresowe lub wózkowe, które skręcały włókno, nadając mu niezbędną wytrzymałość i w takiej postaci dostarczały materiał do tkania na krosnach tkackich (rys. 5) [5].

Z części maszyn włókienniczych, wykonywanych z żeliwa, największe były podstawy maszyn, które bardzo często były narażone na uszkodzenia podczas pracy, jak również w czasie transportu maszyn z fabryki do miejsca zainstalowania, podczas rozpakowywania i montażu. Do ich naprawy stosowano spawanie acetylenowe (rys. 6), jak również lutospawanie (rys. 7).

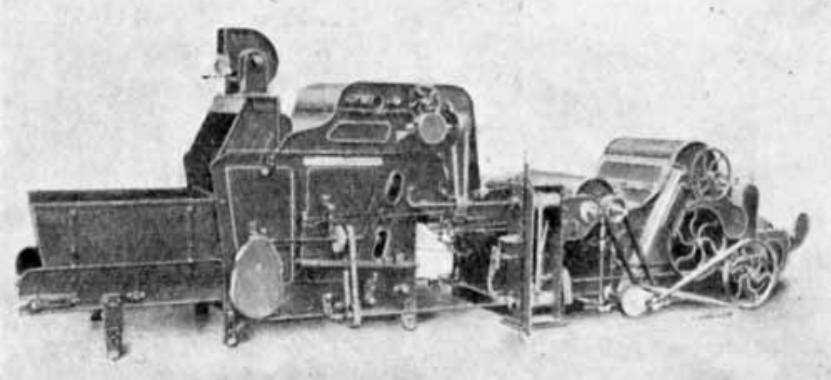

Rys. 1. Trzeparka zwojowa z samozasilaczem skrzynkowym [5] Fig. 1. Scutching lap machine [5]

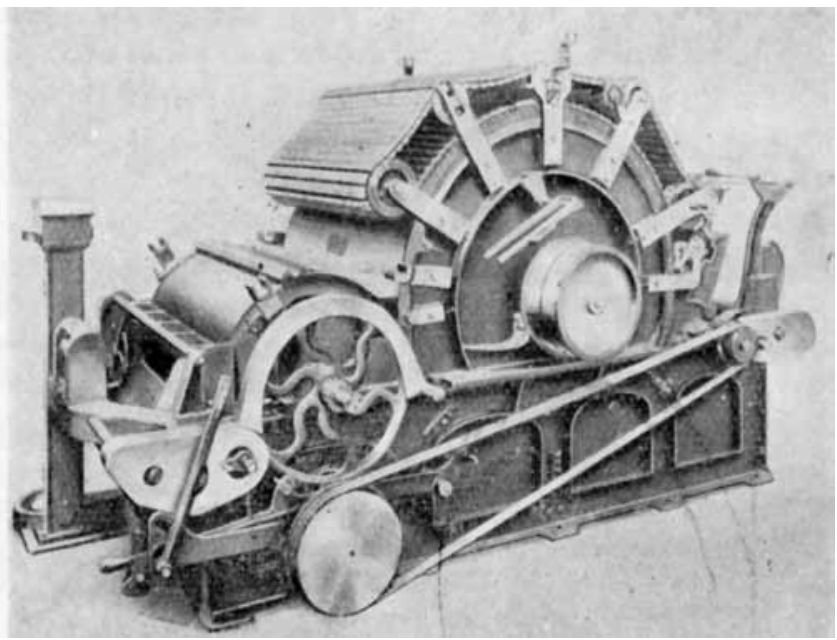

Rys. 2. Zgrzeblarka pokrywkowa [5]

Fig. 2. Flat card [5]

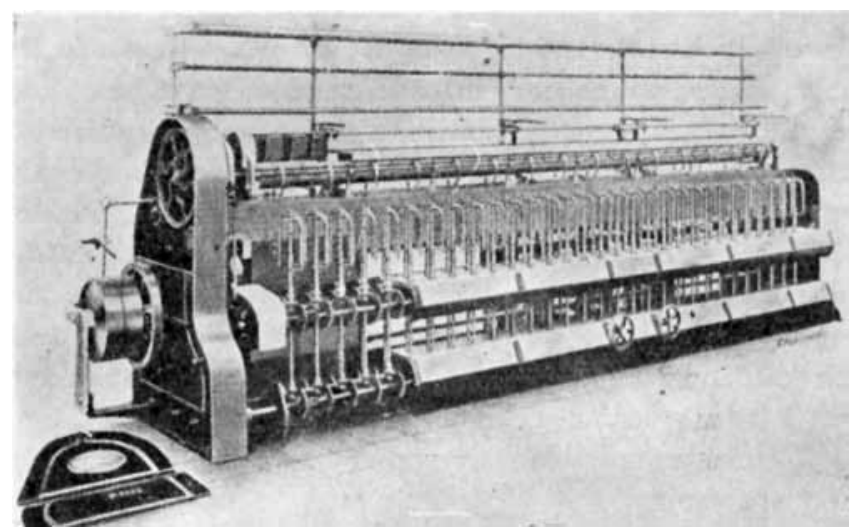

Rys. 3. Wrzecioniarka cienka [5]

Fig. 3. Spindle [5]

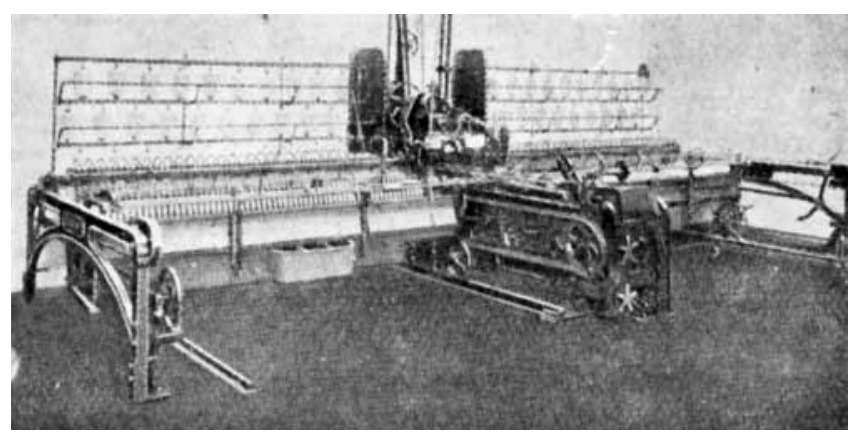

Rys. 4. Przędzarka na 120 wrzecion [5]

Fig. 4. Spinning frame with 120 spindles [5]

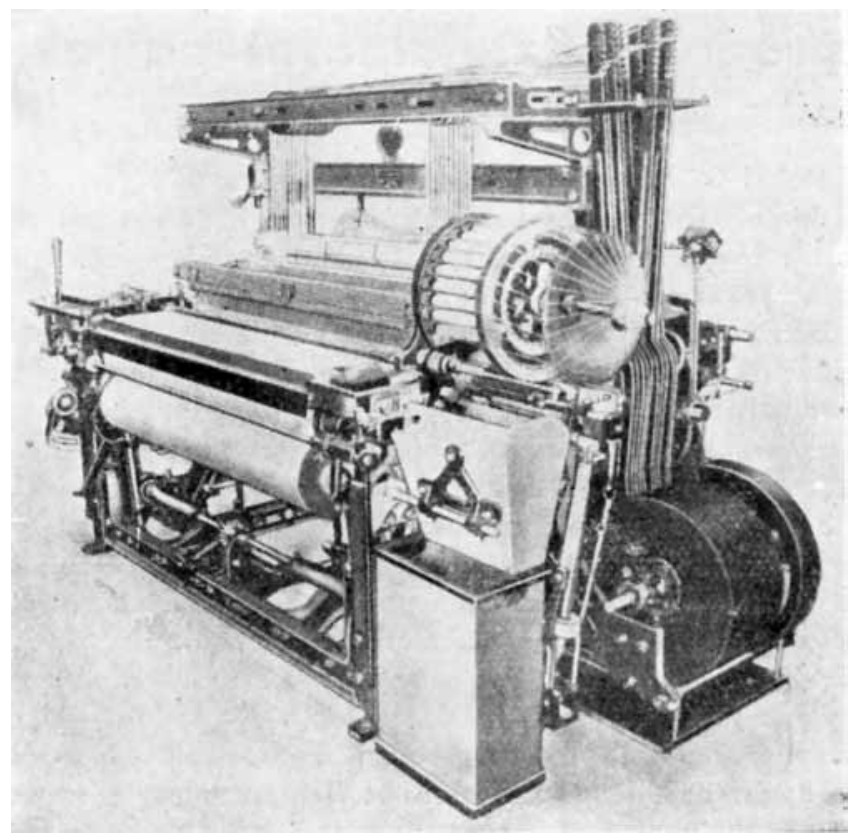

Rys. 5. Krosno tkackie ze zmiennymi kopkami wątkowymi [5]

Fig. 5. Weaving loom with changeable cops [5]

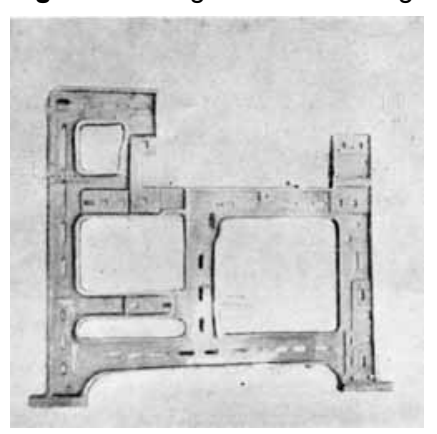

Rys. 6. Żeliwna rama krosna tkackiego naprawiona metodą spawania [2]

Fig. 6. Cast iron frame of weaving loom repaired by welding [2]

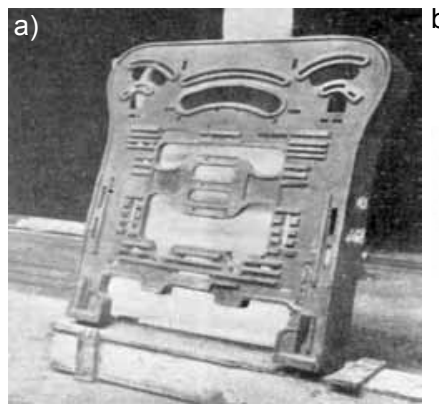

b)

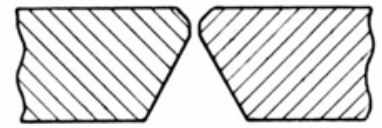

Rys. 7. a) Rama głowicy przędzarki obrączkowej. Pęknięcie w dolnej części naprawione metodą lutospawania; b) ukosowanie brzegów w pęknięciu [2]

Fig. 7. a) Ring-spinning frame head. The crack in the lower part repaired by brazing; b) edges bevel in crack [2] 
Rama przedstawiona na rysunku 6 ma długość $1,5 \mathrm{~m}$, wysokość $1,2 \mathrm{~m}$ i grubość $15 \mathrm{~mm}$. Przygotowanie do naprawy polegało na ukosowaniu palnikiem (prawdopodobnie wytapianiu) i podgrzaniu części w prowizorycznym ognisku. Zastosowano palnik o wydajności $750 \mathrm{l} / \mathrm{h}$, podczas spawania zużyto 2000 I tlenu, $600 \mathrm{~g}$ pałeczek żeliwnych, czas przygotowania do spawania wynosił $2 \mathrm{~h}$, a samego procesu również $2 \mathrm{~h}$ [2].

W głowicy przędzarki obręczkowej (rys. 7) naprawiono pęknięcie o długości $200 \mathrm{~mm}$ (grubość $8 \div 12 \mathrm{~mm}$ ). Przygotowanie do spawania polegało na zukosowaniu pęknięcia na niesymetryczne $X$ (rys. 7b), w celu podpawania od strony dolnej, co polepszyło wytrzymałość i wygląd spoiny. Na obydwóch końcach pęknięcia wywiercono otwory, żeby pęknięcie nie rozprzestrzeniało się wskutek nagrzewania i naprężeń. Podczas naprawy zużyto 400 I tlenu, 315 I acetylenu, $125 \mathrm{~g}$ spoiwa mosiężnego, czas spawania wynosił $1 \mathrm{~h}$. W przypadku napraw podstaw maszyn włókienniczych należało podgrzewać miejscowo elementy spawane, a także, szczególnie gdy stosowano znaczne ilości spoiwa mosiężnego, przekuwać wykonaną spoinę podczas stygnięcia, żeby zapobiec skutkom skurczu złącza [2]. Nie zawsze podgrzewanie miejscowe dawało oczekiwane efekty, czego przykładem jest naprawa czesarki do Inu, popękanej w różnych miejscach (rys. 8).

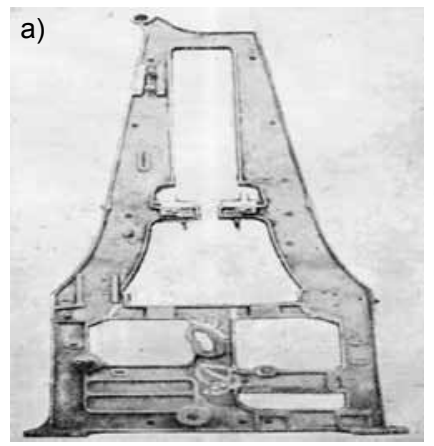

b)

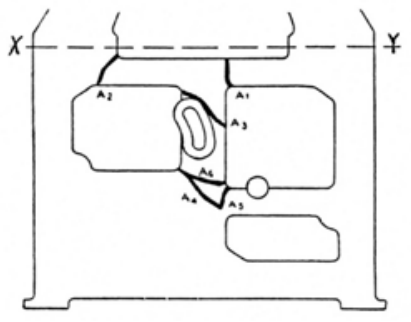

Rys. 8. a) Rama czesarki do Inu, b) pęknięcia w ramie [3]

Fig. 8. a) Frame of hackling machine, b) cracks in the frame [3]

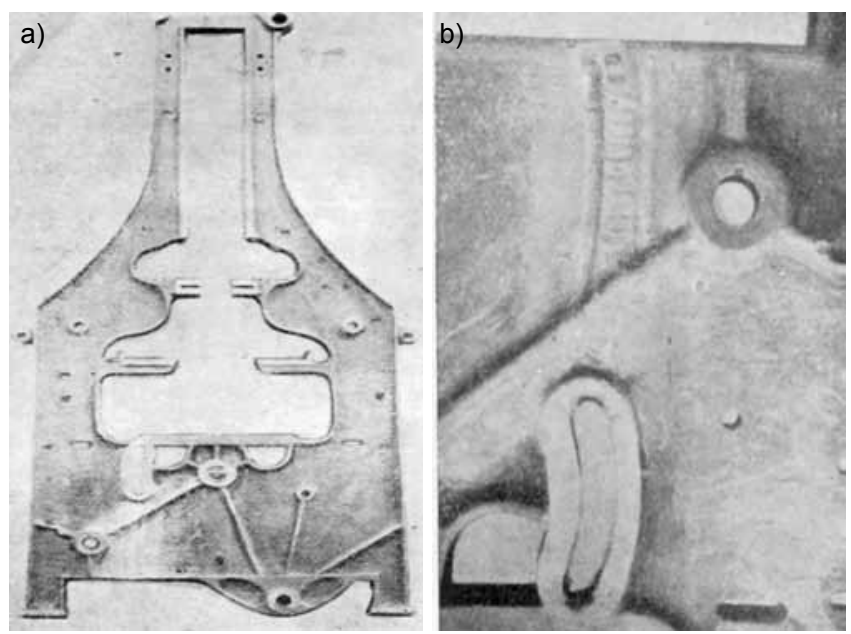

Rys. 9. a) Rama czesarki do Inu naprawiona metodą lutospawania bez uprzedniego podgrzania, b) powiększenie naprawionego miejsca [3]

Fig. 9. a) Frame of hackling machine repaired by brazing without preheating, b) magnification of the repaired place [3]
Czesarki, które były zazwyczaj montowane na ramach, pracowały z szybkością 5 tłoczeń na minutę. Przedstawiona czesarka pracowała z szybkością podwojoną, tj. 10 $\div 12$ tłoczeń na minutę. Powstające przy tym ruchy wywołały znaczne drgania w ramie, wzmocniono ją więc przez dodanie żeber, wskutek czego w dolnej, lewej części ramy grubość materiału wynosiła $85 \mathrm{~mm}$, podczas gdy grubość ścian ramy tylko $15 \mathrm{~mm}$. Spowodowało to wystąpienie wielu niekorzystnych czynników - znacznych naprężeń wewnętrznych powstałych podczas odlewania, utrudniających skurcz po spawaniu - i drgań - powodujących niedostrzegalne pęknięcia.

Ramę naprawiono metodą lutospawania, przy czym zamiast nagrzewania miejscowego trzeba było umieścić całą dolną część ramy (poniżej linii $x-y$, rys. 8b) w prowizorycznym piecu o temperaturze $400^{\circ} \mathrm{C}$.

Czesarki można było również naprawiać bez podgrzania wstępnego, gdyż przy bardzo wydłużonym kształcie ramy nie było niebezpieczeństwa skurczu spoiny obejmującego całą szerokość dolnej blachy ramy (rys. 9). Lutospawanie jednej strony zajęło 55 min, a drugiej $45 \mathrm{~min}$. Do naprawy zużyto 1430 I tlenu, 1300 I rozpuszczonego acetylenu, $240 \mathrm{~g}$ pałek bronzytu o średnicy $3 \mathrm{~mm}$ i $100 \mathrm{~g}$ o średnicy $4 \mathrm{~mm}$ [3].

Poza korpusami maszyn, urządzenia przędzalnicze i tkackie zawierały dużo drobnych elementów, o nieskomplikowanych kształtach, które również ulegały zniszczeniu w wyniku tarcia podczas ruchu (rys. 10).

Dzięki zastosowaniu spawania acetylenowego i lutospawania większość części, które wcześniej były wyrzucane, mogła być ponownie zastosowana. Spawanie na ogół wykonywano na zimno, bez uprzedniego nagrzewania, gdyż w przypadku drobnych i prostych części niebezpieczeństwo związane z rozszerzalnością i skurczem jest minimalne.

Proces naprawy był łatwy, uzyskiwano, więc bardzo dobre wyniki. Należało jednak przestrzegać podstawowych zasad spawania, tj. dobierać palnik odpowiedniej mocy, nie przesuwać zbyt blisko jądra płomienia do jeziorka ciekłego metalu (by nie wypalać węgla i krzemu), używać spoiwa o odpowiedniej zawartości węgla i krzemu, studzić powoli po spawaniu [3].

Oprócz spawania do naprawy elementów stosowano lutospawanie. Jest to metoda łatwa, pozwalająca na szybkie wykonanie naprawy. Czas pracy oraz zużycie materiałów podczas lutospawania żeliwnych elementów przedstawiono w tablicy [6].

Palnik acetylenowo-tlenowy wykorzystywano również do napawania zużytych części urządzeń. Wiele elementów maszyn włókienniczych było narażonych na ruchy o zmiennych kierunkach, a nawet na uderzenie, stąd też konieczność regeneracji zużytych powierzchni.

Do napawania stosowano żeliwo, Bronzyt, Alchrom oraz stale średniowęglowe. Najczęściej napawano żeliwne zęby i koła zębate (rys. 11), a z typowych elementów maszyn włókienniczych: części przędzarki (rys. 12a), przepustki cewiarki (rys. 12b), i mimośród przesuwacza nici łączniarki taśmowej (rys. 12c) [7]. 

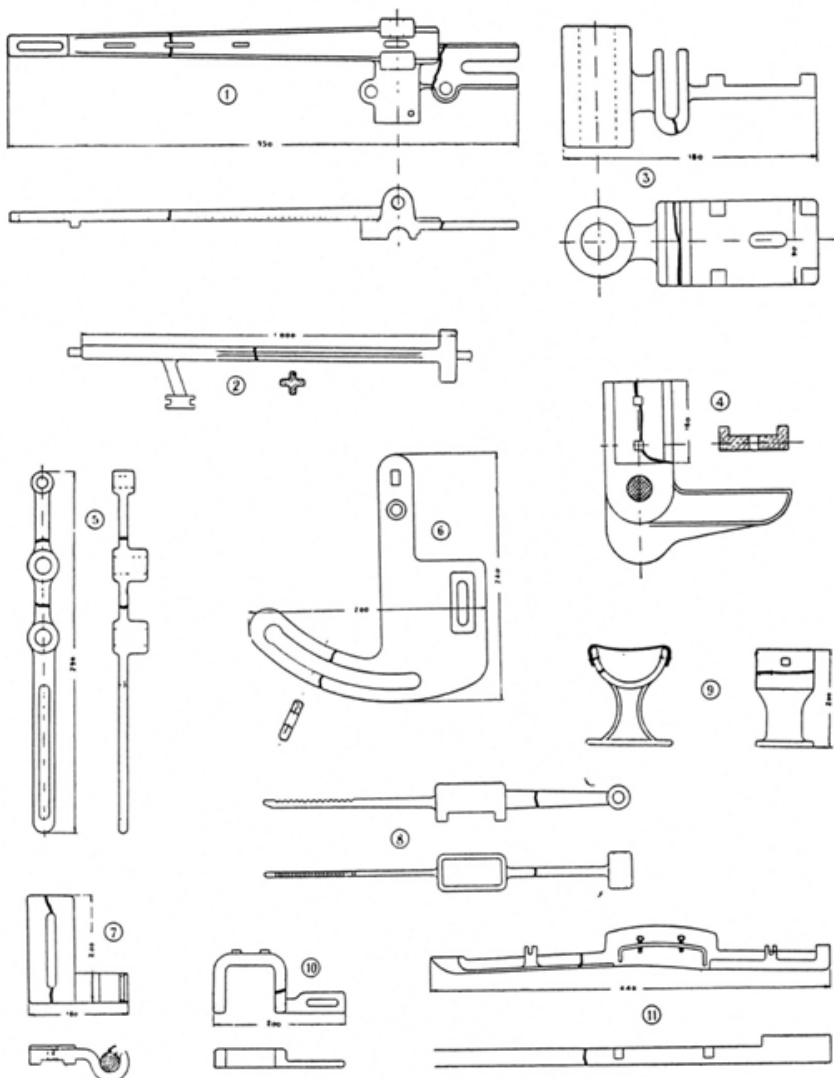

Rys. 10. Typowe żeliwne części maszyn włókienniczych naprawiane za pomocą spawania acetylenowego [3]: 1, 2 - część maszyny tkackiej łącząca wał $z$ elementem przemieszczającym się ruchem wahadłowym, 3 - wspornik łożyskowy pod wał, 4 - wspornik drążka, 5 - drążek regulujący szybkość walca nawijającego, 6 - kulisa do regulowania szybkości przez przesuwanie koła zębatego, 7 - podpora wałka osnowego, 8 - drążek hamulcowy wałka osnowego, 9, 10 - opora i sprężyna zatrzymująca, 11 - boczna ściana czółenka

Fig. 10. Common textile machinery iron cast parts repaired by acetylene welding [3]: 1, 2 - part of the shaft connecting the weaving machine with an element moving pendulum, 3 - the shaft bearing bracket, 4 - support rod, 5 - regulating the speed of the cylinder rod winding, 6 - coolie to regulate the speed of the gear shift, 7 - prop shaft, 8 - brake lever shaft, 9,10 - resistance and spring, 11 - lateral wall of pumps

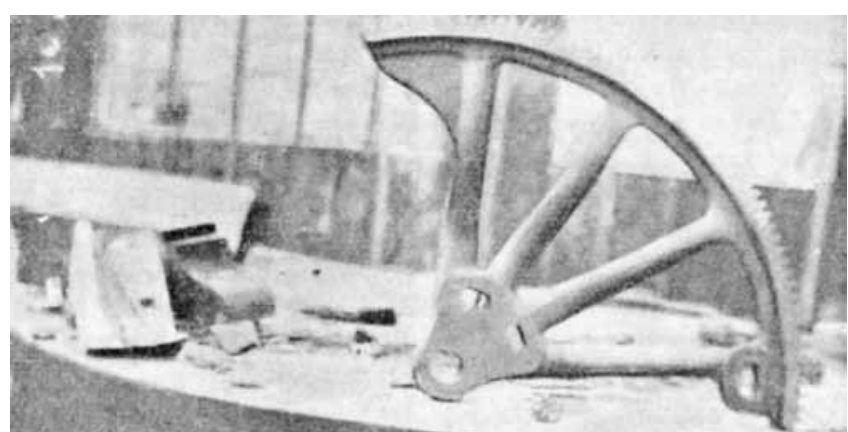

Rys. 11. Wycinek przędzarki wózkowej, na którym 22 zęby naprawiono metodą napawania żeliwa

Fig. 11. Mule spinning frame, in which 22 teeth repaired by welding of cast iron

a)
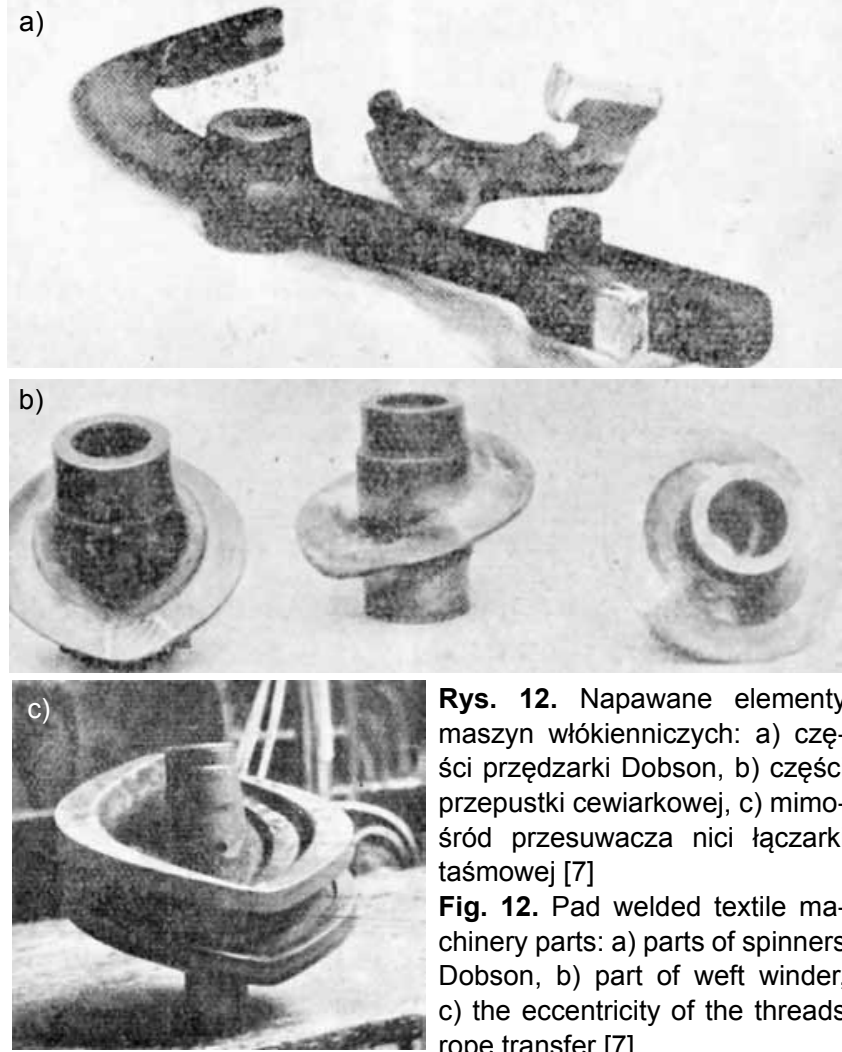

Rys. 12. Napawane elementy maszyn włókienniczych: a) części przędzarki Dobson, b) części przepustki cewiarkowej, c) mimośród przesuwacza nici łączarki taśmowej [7]

Fig. 12. Pad welded textile machinery parts: a) parts of spinners Dobson, b) part of weft winder, c) the eccentricity of the threads rope transfer [7]

Tablica. Zużycie materiałów i czas naprawy części maszyn włókienniczych metodą lutospawania [6]

Table. Costs of materials and time to repair parts of textile machinery by brazing [6]

\begin{tabular}{|c|c|c|c|c|c|c|}
\hline \multirow[b]{2}{*}{ Nazwa części naprawianej } & \multirow[b]{2}{*}{ Rodzaj naprawy } & \multirow{2}{*}{$\begin{array}{c}\text { Masa } \\
\text { części, kg }\end{array}$} & \multirow{2}{*}{$\begin{array}{c}\text { Czas } \\
\text { min }\end{array}$} & \multicolumn{2}{|c|}{ Zużycie } & \multirow{2}{*}{$\begin{array}{l}\text { Wydajność } \\
\text { palnika, } 1 / \mathrm{h}\end{array}$} \\
\hline & & & & tlenu & bronzytu & \\
\hline Część samozastawiacza widelcowego & naprawa pęknięcia w górnym zagięciu & 2,00 & 3 & 12 & 25 & 150 \\
\hline Dżwignia przeciwwagi & naprawa pęknięcia drążka w dolnej części & 5,75 & 14 & 225 & 150 & 750 \\
\hline Prowadnica trąca & naprawa pęknięcia przy otworze górnym & 5,60 & 20 & 300 & 200 & 750 \\
\hline Ramię bidła & naprawa pęknięcia w dolnej części & 11,65 & 12 & 120 & 200 & 500 \\
\hline Dźwignie hamulcowe & naprawa pęknięcia w dolnej części & 4,35 & 8 & 60 & 75 & 350 \\
\hline Drąg korbowy krosna tkackiego & przypawanie ramienia do piasty & 2,25 & 12 & 120 & 130 & 500 \\
\hline Dźwignia wątka & przypawanie jednego $z$ ramion piasty & 4,25 & 12 & 84 & 80 & 350 \\
\hline Suport zwrotnika skrzyni krosien tkackich & naprawa pęknięcia & 2,25 & 16 & 72 & 50 & 350 \\
\hline
\end{tabular}


W warsztatach naprawczych zakładów włókienniczych napawano również części stalowe. Były to m.in. stalowe skrzydełka wrzecionowe używane przy przędzeniu Inu lub konopi, które napawano mosiądzem (rys. 13). Wrzeciona te wykonywały ok. $10 \mathrm{obr} / \mathrm{min}$ i miały skręcać przędzę i nawijać ją na cewkę. Przesuwanie się nici po skrzydełku powodowało powstawanie rowków, co uniemożliwiało właściwą pracę. Skrzydełka odłączano do cewki, napawano Bronzytem i ponownie przylutowywano. Czas naprawy 12 skrzydełek wynosił 55 min, przy rowkach A stosowano palnik o wydajności $150 \mathrm{l} / \mathrm{h}$, a przy rowkach $\mathrm{B}-100 \mathrm{l} / \mathrm{h}$.

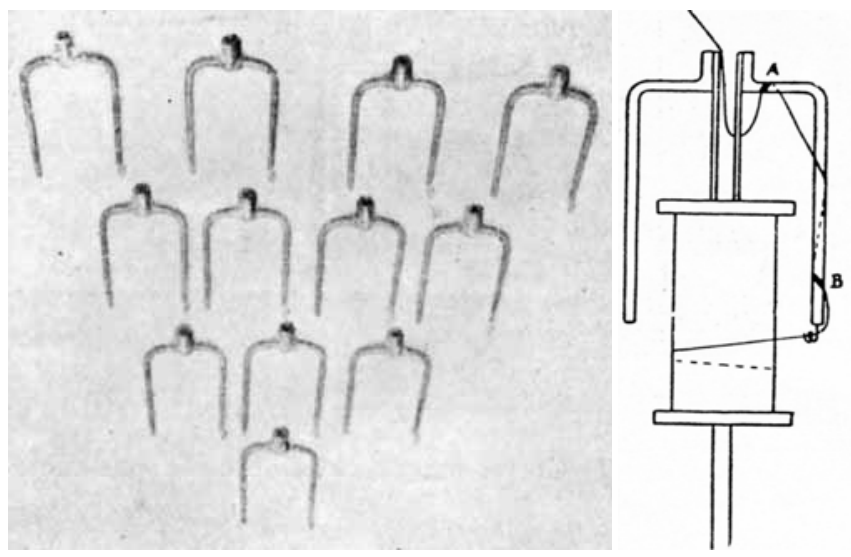

Rys. 13. Stalowe skrzydełka wrzecionowe napawane Bronzytem w miejscach wytartych przez nici oraz schemat wrzeciona z zaznaczonymi miejscami wytarcia; A - rowek podwójny, B - rowek pojedynczy [7] Fig. 13. Steel spindle padded wings bronzite in places worn by the thread, and a scheme with marked locations spindle wear; A - double groove, B - single groove [7]

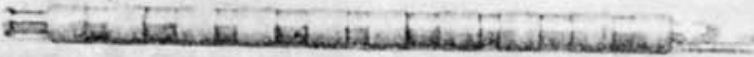

Rys. 14. Stalowy wałek rowkowany przędzarek okresowych napawany stalą [8]

Fig. 14. Grooved steel roller spinners periodic steel padded [8]

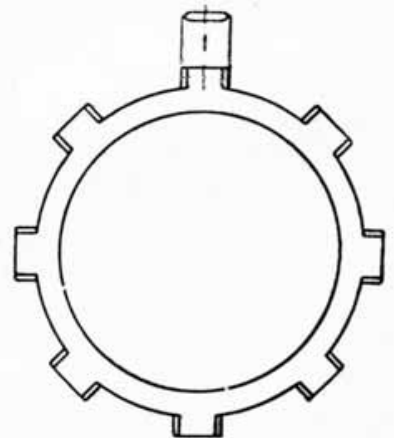

Rys. 15. Noże krajarki Inu napawane stalą średniowęglową [7] Fig. 15. Knives of cutting for flax midsteel padded [7]

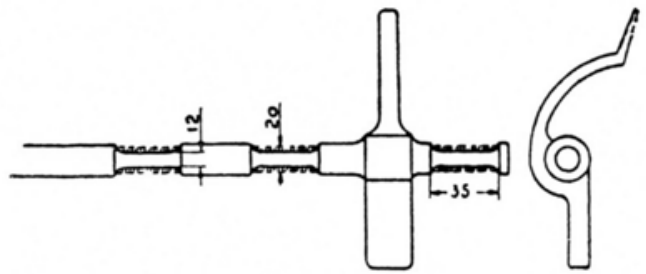

Rys. 16. Drążek bidła krosna tkackiego napawany stalą

Fig. 16. Rod of batten of the loom in the spinning loom frame steel padded

Napoiny stalowe stosowano do regeneracji wałków rowkowanych przędzarki okresowej, noży krajarek do Inu, drążków bidła krosna tkackiego, osi napędowych popychaczy oraz dźwigni sprzęgłowych

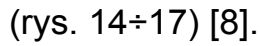

Inne elementy krosien tkackich, np. części grzebieni ruchomych przeznaczonych do wyciągania włókien Inianych lub wełnianych, czy też drążki hamulcowe napawano stosując Alchrom (rys. 18) [8, 9]. W skład krosien tkackich wchodziła znaczna liczba różnych elementów wymagających okresowego napawania, m.in. pieski, płaszki i noże, które napawano żeliwem

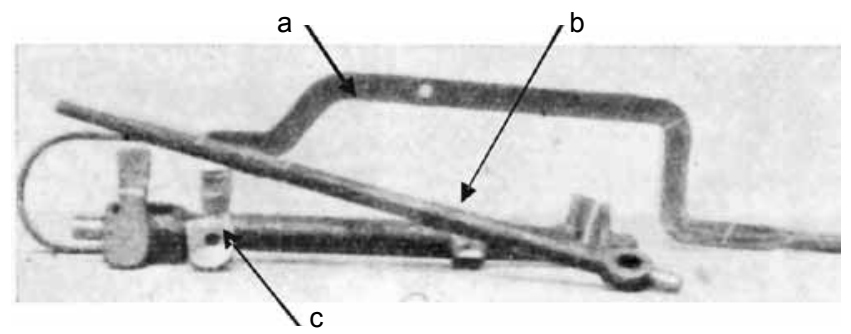

Rys. 17. Części krosna tkackiego napawane stalą: a - oś napędowa, b - oś napędowa-czopy osi napawane, c - popychacze [8]

Fig. 17. Parts of looms steel padded: $a$ - drive axle, $b$ - drive axle, axle studs padded, $\mathrm{c}-$ pushers [8]

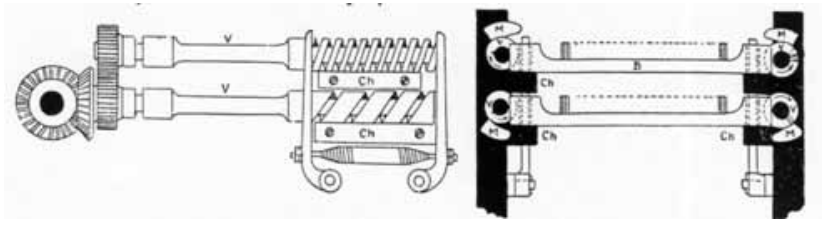

Rys. 18. Schemat działania grzebieni do wyciągania włókien Inianych lub wełnianych [8]

Fig. 18. Diagram of the comb for flax or pulling wool [8]
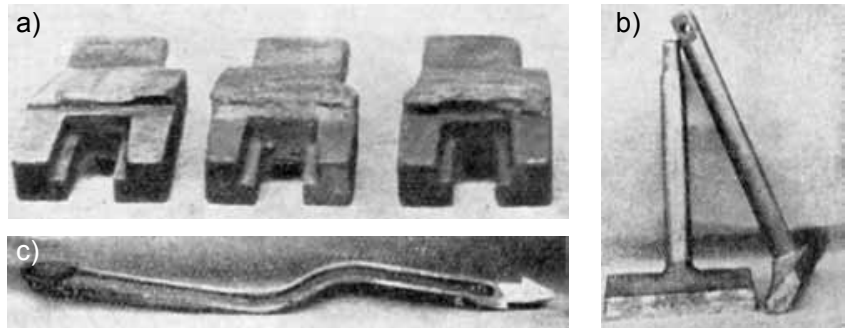

Rys. 19. Elementy napawane krosien tkackich [8]: a) pieski napawane Alchromem, b) nóż sterowy napawany żeliwem, c) płaszki napawane Alchromem

Fig. 19. Surfaced parts of loom [8]: a) „dogs” Alchrom padded, b) rudder blade cast iron padded, c) Alchrom padded part

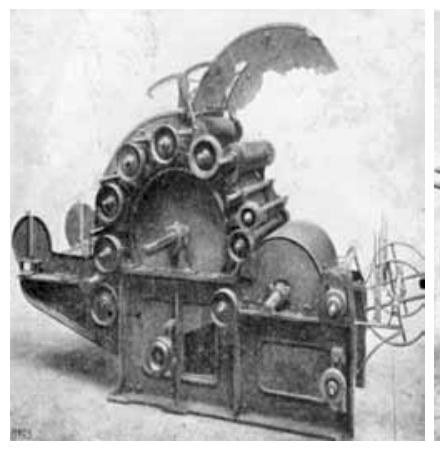

Rys. 20. Zgrzeblarka stalowa [9] Rys. 21. Przyrząd pasemkowy Fig. 20. Steel made carding ma- wykonany ze stali [9] chine [9]

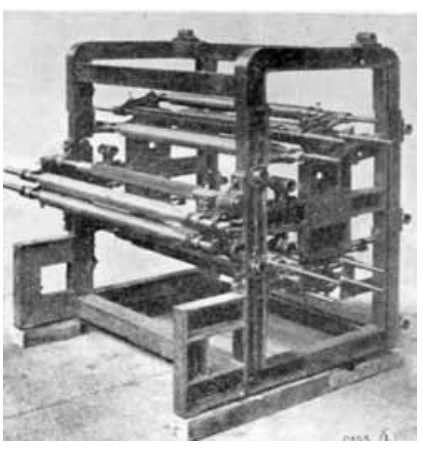

Fig. 21. Lea instrument made by steel [9] 
w przypadku części żeliwnych i Alchromem do części stalowych (rys. 19) [8].

W przedstawionych przypadkach do naprawy i napawania stosowano płomień acetylenowy, a naprawiane elementy były wykonane głównie z żeliwa.

Zakłady Rolando w Chiavazza (Włochy) jako pierwsze zastosowały stal do budowy maszyn włókienniczych. Do wykonania konstrukcji zastosowano cięcie tlenem i spawanie elektryczne. W ten sposób zbudowano zgrzeblarkę (rys. 20), przyrząd pasemkowy (rys. 21) i „wilk” szarpiący (rys. 22) [9].

Maszyny wykonane ze stali były lżejsze i wytrzymalsze, elementy można było hartować powierzchniowo, co dodatkowo zwiększało odporność na zużycie i zmniejszało koszty własne wytwórni włókienniczych. Ten trend z czasem przyszedł do nas i większość elementów maszyn włókienniczych, z wyjątkiem ram, była wykonywana ze stali.

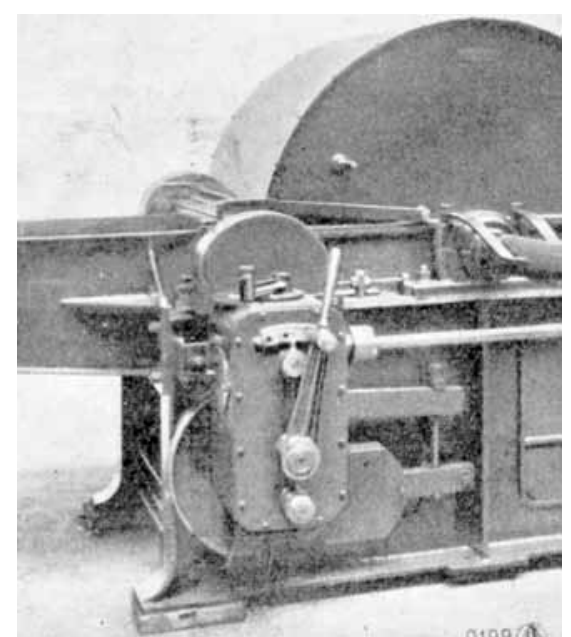

Rys. 22. Przednia część „wilka” szarpiącego wraz z pierwszym bębnem [9]

Fig. 22. View of the front of the wolf struggling with the first drum [9]

\section{Literatura}

[1] Zastosowanie spawania w przemyśle włókienniczym. Spawanie i Cięcie Metali, nr 6, 1929, s. 103-106.

[2] Spawanie w przemyśle włókienniczym. Spawanie i Cięcie Metali, nr 1, 1938, s. 11-15.

[3] Spawanie w przemyśle włókienniczym. Spawanie i Cięcie Metali, nr 2, 1938, s. 39-43.

[4] Spawanie w przemyśle włókienniczym. Spawanie i Cięcie Metali, nr 3, 1938, s. 59-62.

[5] Spawanie w przemyśle włókienniczym. Spawanie i Cięcie Metali, $n r$ 4, 1938, s. 83-85.
[6] Spawanie w przemyśle włókienniczym. Spawanie i Cięcie Metali, nr 5, 1938, s.101-104.

[7] Spawanie w przemyśle włókienniczym. Spawanie i Cięcie Metali, nr 7, 1938, s. 146-148.

[8] Spawanie w przemyśle włókienniczym. Spawanie i Cięcie Metali, nr 8, 1938, s. 168-171.

[9] Spawanie w przemyśle włókienniczym. Spawanie i Cięcie Metali, nr 9, 1938, s. 186-189.

\section{SpawnhryIcTü \\ www.pspaw.ps.pl}

